UDC [620.1'18'19]:[621.793.16]:66.018.8

\title{
STRUCTURAL FEATURES OF CHROMIUM CARBID COATINGS OBTAINED BY THE MOCVD METHOD FROM THE COL "BARKHOS"
}

\author{
S.A. Krokhmal, Yu.G. Kazarinov, T.N. Zueva \\ National Science Center “Kharkov Institute of Physics and Technology”, Kharkiv, Ukraine \\ E-mail: krokhmal@kipt.kharkov.ua
}

Investigations of the structure and properties of gas-phase coatings obtained with the use of chromium organic liquid (COL) "Barkhos" have been carried out. The studies were carried out by the methods of nanoindentation, fractography, and X-ray photoelectron spectroscopy. It was found that such coatings have a two-level horizontallayered structure.

One of the ways to increase the wear resistance of parts is to apply protective coatings on their working surfaces. In this case, the operational properties of products are determined by their structural and phase characteristics.

Chromium carbide coatings have high corrosion and erosion resistance, which leads to their wide industrial application. Of particular interest are coatings obtained from bis-arene chromium compounds [1-7]. These coatings have a higher, in comparison with coatings based on chromium carbide, both wear resistance and resistance to chemical dissolution in aggressive media $[1,5,7]$. However, the widespread use of such coatings is limited by the high cost of individual bis-arene compounds. In this regard, it is of interest to study the possibility of obtaining coatings using a cheap technical product COL "Barkhos", produced by an industrial method (TC-6-01-1149-78). Coatings obtained using this COL can have an amorphous, horizontally layered, columnar and dendritic structure.

Of particular interest are chromium carbide coatings with a horizontally layered structure. Such chromiumbased laminated metal-ceramic coatings of the type $\mathrm{Cr} / \mathrm{CrC}_{\mathrm{X}}$ in their mechanical and tribological properties, they are noticeably superior to single-component coatings obtained from individual components of these layers [8, 9]. The reason for the anomalously high resistance of such coatings can be both the features of their chemical and phase composition, structure, and the size of the structural elements of the coating. Studies [10] showed that with a decrease in the thickness of layers in a layered coating, there is a decrease in the size of nanocrystallites in the layer and an increase in the hardness of the coatings, which leads to an improvement in their operational properties.

The aim of this work is to study the features of the structure of coatings obtained by the MOCVD (Metalorganic chemical vapor deposition) method using the technical product COL "Barkhos" at various deposition parameters, as well as to clarify the reasons for their abnormally high corrosion and erosion resistance.

\section{MATERIAL AND RESEARCH METHODS}

The deposition of coatings was carried out on a flow-through installation at a reduced pressure, a schematic diagram of which is shown in Fig. 1. The reaction volume was heated to the required temperature by high frequency currents. The deposition of coatings was carried out both with the use of dibenzyl ether (DBE) additives and without it. DBE (3\%) was added to the original precursor. The temperature of the substrate during deposition was $400 \ldots 530^{\circ} \mathrm{C}$, and the feed rate of the Barkhos liquid chemical liquid was $3 \ldots 7.5 \mathrm{~g} / \mathrm{h}$, with constant evacuation from the reaction zone.

The study of the structure and properties of the coating was carried out on transverse thin sections using the Murkami reagent as an etchant, as well as by fractography methods using a JSM-7001F scanning microscope and Nano Indentor G-200. Also, to study the elemental and phase composition of chromium carbide coatings, methods of X-ray photoelectron spectroscopy (XPS) were used.

\section{EXPERIMENTAL SECTION}

As a result of the experiments, chromium carbide coatings with amorphous, horizontally layered and layered columnar structures were obtained (Fig. 2).

An increase in the deposition temperature to $400 \ldots 430^{\circ} \mathrm{C}$ led to the formation of coating layers with a thickness of $350 \ldots 400 \mathrm{~nm}$ (Fig. 3,a). With an increase in the deposition temperature, the growth of horizontally layered coatings was also observed (see Fig. 3,b). The deposition process was carried out in the cooling mode of a massive sample for $2 \ldots 2.5 \mathrm{~min}$, the average deposition rate of the coating was at the level of $5 \ldots 6 \mu \mathrm{m} / \mathrm{min}$, and its thickness was $\approx 14 \mu \mathrm{m}$. The precursor was fed once, which led to a gradual decrease in the rate of its entry into the deposition zone. As a result, in the process of deposition, more and more thin layers of the coating were formed (see Fig. 3,b).

The formation of a thin sublayer with a columnar structure $\sim 1 \mu \mathrm{m}$ thick at the initial stage of the deposition process is due to the higher substrate temperature, which decreases due to the high endothermicity of the deposition process and the absence of decomposition products at this stage, which complicate the access of precursor vapors to the deposition surface.

The next coating layer has a less pronounced columnar structure. Further, the deposition process proceeds with the formation of clearly defined horizontal layers of the coating. The thickness of these layers decreases from $\approx 1$ to $\approx 0.5 \mu \mathrm{m}$. This is due to the establishment of a certain ratio between the rate of 
formation of gaseous decomposition products and the rate of their pumping out of the reaction zone. Image processing Fig. 3,b made it possible to reveal the existence of sublayers in the coating layers, which are hardly noticeable in the original photo. Further studies of such chromium carbide coatings using XPS methods and analysis of fractograms of oblique fractures of the coating confirmed the presence of such coating sublayers.

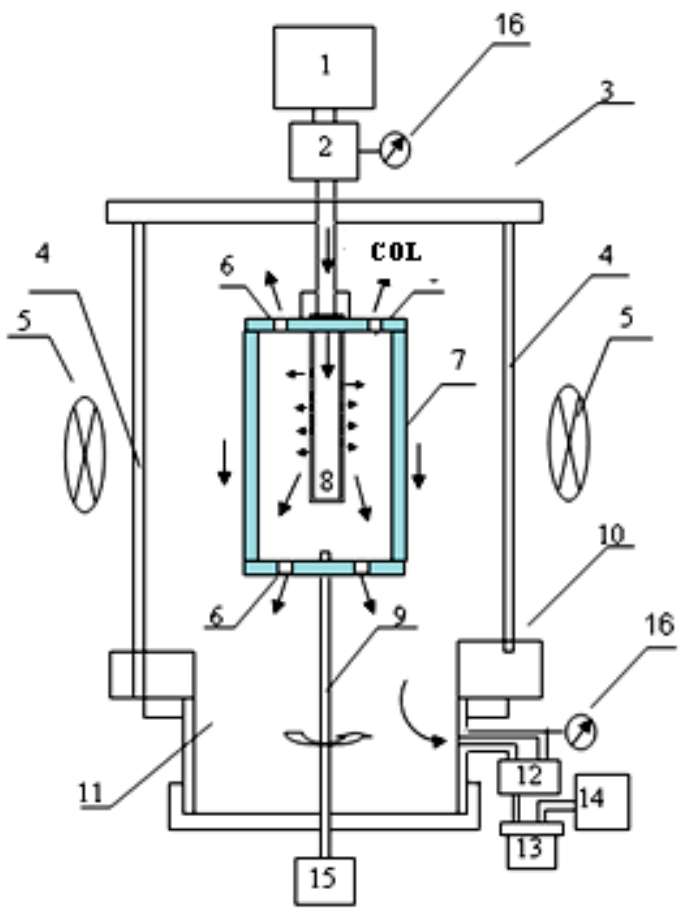

1 - feed container
2 - dispenser
3 - upper flange reaction
chamber
4 - quartz wall of the
reaction chamber
5 - RF inductor
6 - pumping holes
7 - reaction volume
8 - distribution nozzle
9 - input rotation
10 - the lower flange of the
reaction chamber
11 - sluice chamber
12 - nitrogen trap
13 - container
14 - pumping system
15 - engine rotation
16 - pressure sensors

Fig. 1. Schematic diagram of the installation for the deposition of chromium carbide coatings

Studies of the structure of chromium carbide coatings using a scanning electron microscope (SEM) showed that, in addition to layers with a thickness of 0.5 to $2 \mu \mathrm{m}$, there are thinner layers in the coating. These layers are not visible when fractured along the normal to the growth surface, but they are clearly visible when the coating is fractured at an angle of $\sim 45^{\circ}$ (Fig. 4).
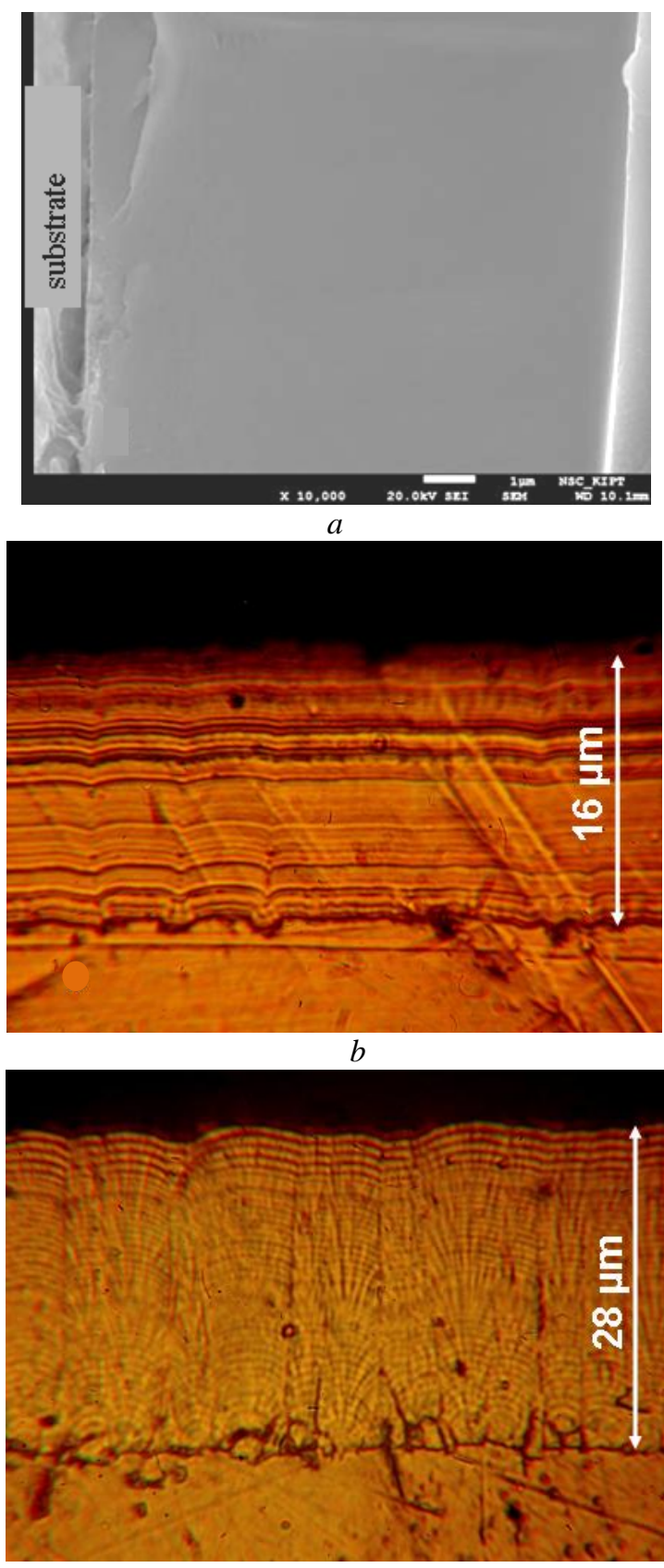

$c$

Fig. 2. Structures of chromium carbide coatings obtained by the MOCVD method from the Barkhos

liquid cooling system in the temperature range of $400 \ldots 500{ }^{\circ} \mathrm{C}:$ a-amorphous;

$b$-horizontally layered; $c$-layered-columnar

The section of an oblique fracture of the coating obtained at a higher magnification (Fig. 5) allows one to more accurately estimate the thickness of the layers. According to our estimates, the height of these steps is at a level of $\sim 40 \ldots 60 \mu \mathrm{m}$.

The data of studies carried out by the method of XPS also showed that the thickness of the coating sublayers corresponds to the data obtained using SEM (Fig. 6).

The distribution of elements in the near-surface layer of a chromium carbide coating to a depth of $150 \mathrm{~nm}$ is a consequence of the final stage of the deposition process. 

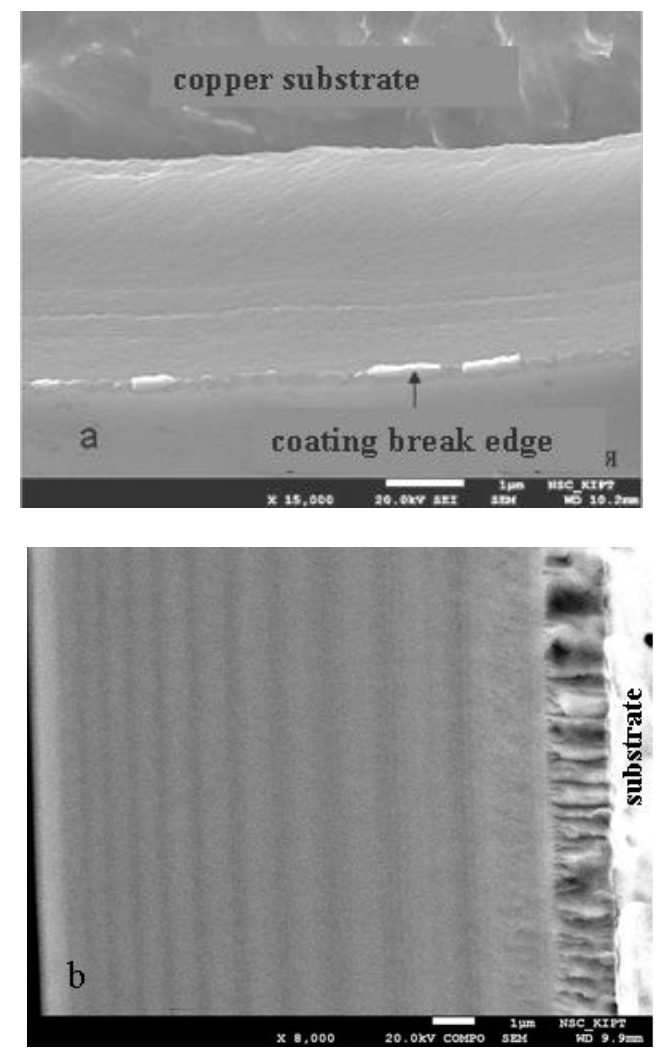

Fig. 3. Carbide-chromium coatings obtained on copper substrates at different deposition temperatures: $a-420 \ldots 400{ }^{\circ} \mathrm{C} ; b-500 \ldots 480{ }^{\circ} \mathrm{C}$

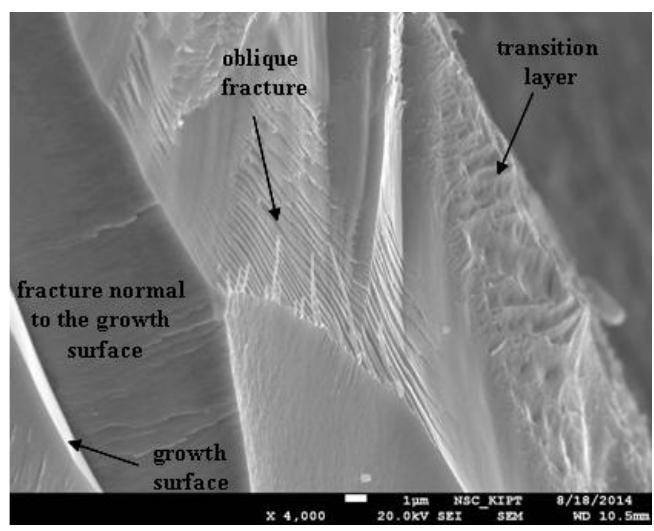

Fig. 4. Complex fracture of a chromium carbide coating obtained at Tos- $i=430{ }^{\circ} \mathrm{C}$ without the use of dibenzyl ether additive

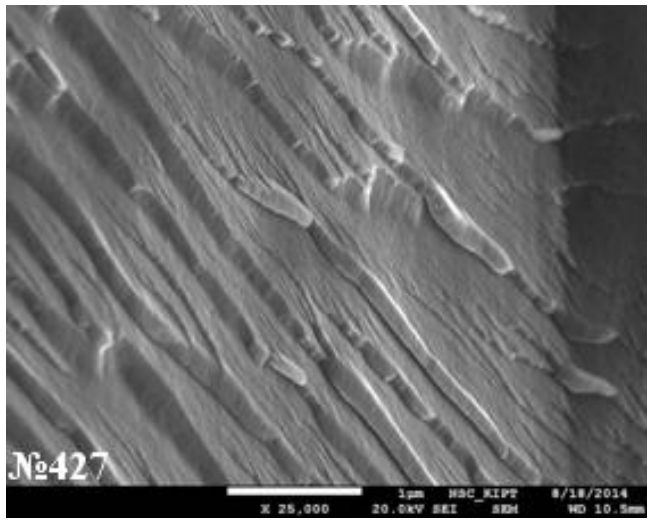

Fig. 5. An enlarged fragment of an oblique fracture of a chromium carbide coating obtained at $T_{\text {dep }}=430^{\circ} \mathrm{C}$ without the use of dibenzyl ether additive

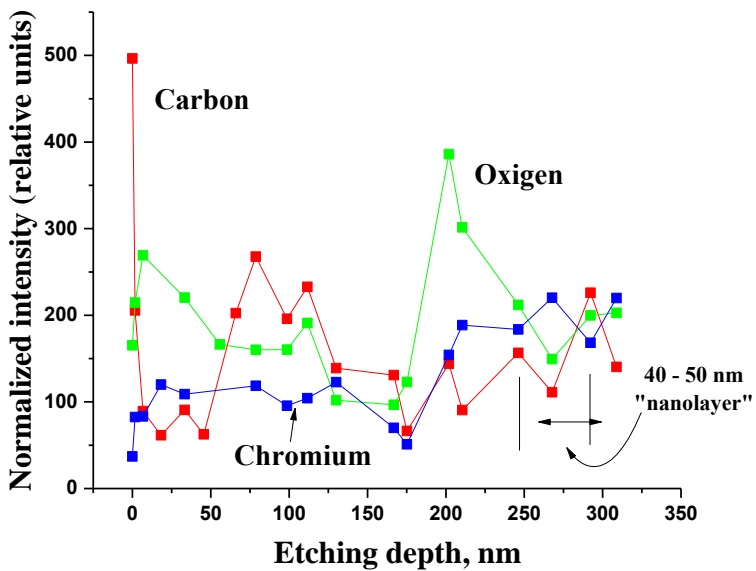

Fig. 6. Profiles of distribution of chemical elements over the thickness of the coating obtained by XPS methods
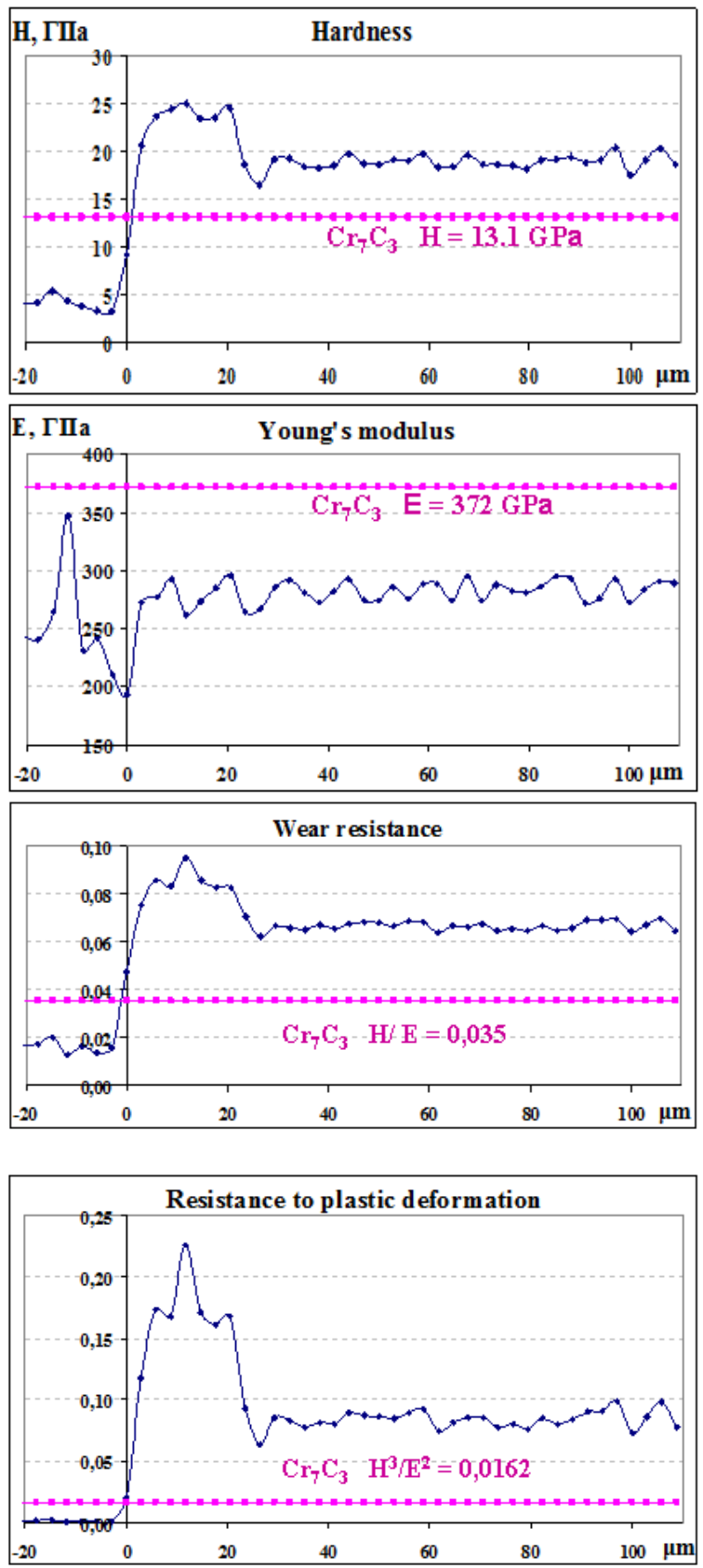

Fig. 7. Comparative data on the properties of chromium carbide coating and tabular data on the properties of $\mathrm{Cr}_{7} \mathrm{C}_{3}$ [16] 
After stopping the supply of the precursor and turning off the heating of the samples, they were taken out into the airlock, which was cut off from the reaction volume, and the atmosphere was puffed into it $(0.5 \ldots 1 \mathrm{~min})$. Due to the presence of a certain amount of precursor on the walls of the lock chamber, the presence of oxygen and the high temperature of the samples, the surface layer of the coating is enriched with oxygen and carbon. Upon completion of the deposition process and cooling of the samples inside the reaction volume, the surface of the sample was covered with "tarnishing colors" due to the presence of incomplete decomposition products of the precursor (hydrocarbons) in the reaction volume and a temperature sufficient for their interaction with the coating surface. In this case, it was possible to observe a smooth color change on the surface of the samples during their cooling [11]. As a result, the samples had a "non-marketable appearance", and the duration of the process increased significantly.

Studies of the effect of the layering of coatings on their operational properties $[12,13]$ indicate that with a decrease in the thickness of the layers, the resistance of the coatings is higher than that of the materials included in their composition.

Measurements of hardness and Young's modulus of chromium carbide coatings, carried out by the Oliver and Farr [14] method, and an assessment of their performance properties showed that they have higher hardness, wear resistance and resistance to plastic deformation than chromium carbide included in their composition (Fig. 7). Cavitation tests of these coatings showed that their resistance is several times higher than that of such steels as KhVG, 12Kh18N10T, 20Kh13 [15].

\section{CONCLUSIONS}

It has been shown experimentally that chromium carbide coatings obtained from COL "Barkhos" and having a horizontally layered structure at the microlevel $(0.5 \ldots 2 \mu \mathrm{m})$ have sublayers $30 \ldots 50 \mathrm{~nm}$ thick, consisting mainly of chromium, carbon and oxygen.

The increased durability of such coatings is due to both the thickness of the layers in the coating and the dimensions of the structural elements of the coating layers.

To analyze the chemical compounds that make up the coating, further studies are required by XPS methods with a resolution of $0.1 \mathrm{eV}$ of the analyzed electron energy.

\section{REFERENCES}

1. Применение металлоорганических соединений для получения неорганических покрытий $и$ материалов / Отв. ред. Г.А. Разуваев. М.: «Наука», 1986, $256 \mathrm{c}$.

2. Осаждение пленок и покрытий разложением металлоорганических соединений / Отв. ред. Г.А. Разуваев. М.: «Наука», 1981, 322 с.

3. Ю.М. Лахтин, Я.Д. Коган, А.П. Горовой и др. Износостойкость пиролитических карбидохромовых покрытий при абразивном и гидроабразивном воздействиях // IV Всесоюзное совещчание «Приме- нение металлоорганических соединений для получения неорганических покрытий и материалов». Горький, 21-23 сентября 1983 г. М., 1983, c. $150-151$.

4. Ю.М. Лахтин, Я.Д. Коган, А.П. Горовой, В.М. Струлев. Исследование физико-механических свойств пиролитических хромовых покрытий // V Всесоюзное совещание «Применение металлоорганических соединений для получения неорганических покрытий и материалов», Горький, 1987: Тез. докл. М.: «Наука», 1987, с. 68-71.

5. В.А. Костенков. Исследование проиессов химического осаждения покрытий карбида хрома из паровой фазы бис-аренхроморганических соединений: Дис. канд. ... техн. наук. Л.: «Ленинград. технолог. ин-т», 1978, 131 с.

6. Ю.М. Лахтин, Я.Д. Коган, А.П. Горовой, Л.Л. Иванов. Упрочнение режущего инструмента пиролитическими хромовыми покрытиями // Техника, экономика, информащия. Серия «Технология». 1988 , в. 4, с. 34-41.

7. В.А. Костенков, В.Н. Крашенинников, В.А. Качанов и др. Оценка химической стойкости пиролитических карбидохромовых покрытий // IV Всесоюзное совещание: "Применение металлоорганических соединений для получения неорганических покрытий и материалов», Горький, 1983: Тез. докл. М.: «Наука», 1983, с. 148.

8. J. Romero, A. Lousa, E. Martınez, J. Esteve. Nanometric chromium /chromium carbide multilayers for tribological applications // Surface and Coatings Technology. 2003, N 163-164, p. 392-397.

9. M.A. Gomez, J. Romero, A. Lousa, J. Esteve. Tribological performance of chromium /chromium carbide multilayers deposited by r. f. magnetron sputtering // Surface and Coatings Technology. 2005, v. 200, p. 1819-1824.

10. Peidong Xue, Lei Yang, Dongfeng Diao Nanocrystalline/amorphous biphase enhanced mechanical properties in multilayer carbon films // Surface and Coatings Technology. 2018, v. 334, p. 1-6.

11. В.В. Мельников, Г.А. Максимов, Б.С. Каверин и др. Состав и структура покрытий, осажденных из паровой фазы при термораспаде бис-аренхромовых комплексов // ДАН СССР. 1974, т. 219, №4, c. 929-931.

12. M.A. Gomez, J. Romero, A. Lousa, J. Esteve. Tribological performance of chromium/chromium carbide multilayers deposited by r.f. magnetron sputtering // Surface and Coatings Technology. 2005, v. 200, N 5-6, p. 1819-1824.

13. J. Romero, A. Lousa, E. Martınez, J. Esteve. Nanometric chromium /chromium carbide multilayers for tribological applications // Surface and Coatings Technology. 2003, v. 163-164, p. 392-397.

14. W.C. Oliver, G.M. Pharr. An improved technique for determining hardness and elastic modulus using load and displacement sensing indentation experiments // J. Mater. Res. 1992, v. 7, N 6, p. 15641583.

15. С.А. Крохмаль. Увеличение стойкости сложнопрофильных деталей узлов запорной арматуры, используемой в оборудовании АЭС и 
ТЭС / Проблеми ресурсу $i$ безпеки експлуатації конструкцій, споруд та машин. Збірник наукових статей IЕЗ ім. Є.О. Патона НАН Украӥни: Київ, 2012, c. $180-185$.
16. Т.Я. Косолапова. Карбиды. М.: «Металлургия», 1968, 300 с.

\title{
ОСОБЕННОСТИ СТРУКТУРЫ КАРБИДОХРОМОВЫХ ПОКРЫТИЙ, ПОЛУЧАЕМЫХ МЕТОДОМ МОСУD ИЗ ХОЖ «БАРХОС»
}

\author{
С.А. Крохмаль, Ю.Г. Казаринов, Т.Н. Зуева
}

Проведено исследование структуры и свойств газофазных покрытий, получаемых с использованием хромоорганической жидкости (ХОЖ) «Бархос». Исследования проводили методами наноиндентирования, фрактографии и рентгеновской фотоэлектронной спектроскопии. Установлено, что такие покрытия имеют двухуровневую горизонтально-слоистую структуру.

\section{ОСОБЛИВОСТІ СТРУКТУРИ КАРБДОХРОМОВИХ ПОКРИТТІВ, ОТРИМАНИХ МЕТОДОМ МОСУD 3 ХОР «БАРХОС»}

\section{С.О. Крохмаль, Ю. Г. Казарінов, Т.М. Зуєва}

Проведено дослідження структури і властивостей газофазних покриттів, одержуваних з використанням хромоорганічної рідини (ХОР) «Бархос». Дослідження проводили методами наноіндентування, фрактографії i рентгенівської фотоелектронної спектроскопії. Встановлено, що такі покриття мають дворівневу горизонтально-шарувату структуру. 